\title{
Study Elements Traces in the Cassava Semolina (Attieke) Coming from the Town of Grand-Lahou, Dabou and Bonoua
}

\author{
Diaby Vandjiguiba ${ }^{1 *}$, Gnonsoro Urbain Paul ${ }^{2}$, Ake Assi Yolande ${ }^{1}$, KOFFI Kouamé Mathias ${ }^{1}$, Sanogo Isiaka ${ }^{1}$, Yapo Adou Francis ${ }^{3}$, \\ Ardjouma Dembele ${ }^{2}$ \\ ${ }^{1}$ Central Laboratory for the Food Hygiene and Agricultural Processing Industry, LANADA, Ministry for Agriculture and the Rural Development, 04 \\ BP 612 Abidjan 04 \\ ${ }^{2}$ Central laboratory of Agrochemicals and Ecotoxicology (LCAE), LANADA, 04 BP 612 Abidjan 04, Côte, d'ivoire \\ ${ }^{3}$ Laboratory of Pharmacodynamics-Biochemical, UFR Biosciences, University FELIX Houphouët Boigny-Abidjan (Côte.d'ivoire), 22 BP 582 Abidjan \\ 22
}

\section{Article History \\ Received: 05.12.2020 \\ Accepted: 17.12 .2020 \\ Published: 25.12.2020 \\ Journal homepage: \\ http://www.easpublisher.com}

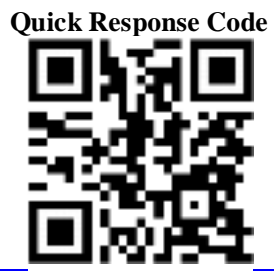

Abstract: The aim of this study was to assess the health quality of cassava meal (attiéké) sold in various regions by testing for trace elements. To do this, 30 samples of attiéké were taken due to 10 samples per city (Grand-Lahou, Dabou and Bonoua) which are areas of high production of attiéké. These samples were mineralized and their arsenic, cadmium and lead contents were evaluated by atomic absorption spectrometry (AAS). Thus, 90 tests were carried out. The results obtained showed the presence of lead, arsenic and cadmium in the samples analyzed. The average arsenic content was $0.229 \pm 0.050$ $\mathrm{mg} / \mathrm{kg} ; 0.053 \pm 0.03 \mathrm{mg} / \mathrm{kg}$ and $0.039 \pm 0.00 \mathrm{mg} / \mathrm{kg}$ respectively for the cities of Grand-Lahou, DABOU and Bonoua. With regard to lead, the content was $0.444 \pm 0.30$ $\mathrm{mg} / \mathrm{kg}$ for Grand-Lahou, for Dabou, this content was $0.387 \pm 0.281 \mathrm{mg} / \mathrm{kg}$ and $0.451 \pm$ $0.266 \mathrm{mg} / \mathrm{kg}$ for the city of Bonoua. As for cadmium, the levels were $0.0106 \pm 0.0102$ $\mathrm{mg} / \mathrm{kg}, 0.002 \pm 0.00 \mathrm{mg} / \mathrm{kg}$ and $0.0110 \pm 0.00 \mathrm{mg} / \mathrm{kg}$ respectively for the towns of Bonoua and Grand-Lahou and Dabou. The presence of metallic trace elements above the standard $(0.1 \mathrm{mg} / \mathrm{kg})$ for arsenic and lead in the attiéké sold in Côte d'Ivoire should prompt systematic health checks for the well-being of consumers.

Keywords: Cassava semolina, Attiéké, Metal trace element (ETM), Atomic absorption spectrometry (AAS) and Ivory Coast.

Copyright (C) 2020 The Author(s): This is an open-access article distributed under the terms of the Creative Commons Attribution 4.0 International License (CC BY-NC 4.0) which permits unrestricted use, distribution, and reproduction in any medium for non-commercial use provided the original author and source are credited.

\section{INTRODUCTION}

Cassava root (Manihot esculenta) is the fourth largest crop for its contribution to the diet of the world population after wheat, maize, and rice [1]. Cassava roots are of significant socio-economic interest due to their relatively low cost, ease and speed of culinary preparation [2]. Indeed, world cassava root production was estimated at around 257 million tonnes in 2012, including 146 million tonnes from Africa, or $57 \%$ of this production [3, 4]. Also by the volume of its production and consumption, cassava is the staple food par excellence of 800 million people living in the Third World. However, cassava is a very perishable product and can be stored in the open air for no more than two to three days [5].

In Côte d'Ivoire, attiéké, derived from the processing of cassava root, is the most consumed fermented product [6, 7]. It is steamed before consumption and comes in the form of detached grains [4]. The annual production of attiéké is estimated between 18,965 tonnes and 40,000 tonnes. As for the annual consumption, it varies between $28 \mathrm{~kg}$ and $30 \mathrm{~kg}$ per capita [1]. This met is one of the main sources of energy in the diet of Ivorians. However, the contamination of this product by pollutants, and in particular heavy metals, is a major societal concern [2]. Indeed, agricultural and industrial activities sometimes require the use of pesticides and fertilizers which lead to contamination with trace elements and other organic components constituting pollutants for the environment [8]. The trace elements best known for their dangerousness are leading $(\mathrm{Pb})$, mercury $(\mathrm{Hg})$, cadmium $(\mathrm{Cd})$, chromium $(\mathrm{Cr})$, copper $(\mathrm{Cu})$, nickel (Ni), and zinc ( $\mathrm{Zn})$ [9]. Indeed, these trace elements pass quite easily through the food chain [2]. Once transferred to humans through the digestive tract, these trace elements combine with organic sulfur compounds in our bodies to cause serious disorders. According to a study by Adjagodo [10], the levels of trace elements obtained in these agricultural soils are due to the use of phosphate fertilizers. Also, the work of Kouamé [11] highlighted the presence of heavy metals in cassava roots intended for the production of attièké in Côted'Ivoire. Faced with this, what is the sanitary quality of 
cassava semolina (attieké)? Thus, taking into account the gastronomic, socio-economic and socio-sanitary importance of this product, the objective of this study was to study the sanitary quality of attiéké by the search for metallic trace elements that are arsenic, lead and cadmium.

\section{Materials ANd Methods}

\section{Sampling technique}

30 samples of cassava semolina (attiéké) whose weights varied between $200 \mathrm{~g}$ and $300 \mathrm{~g}$ were taken in three large cities producing attiéké (GrandLahou, Dabou and Bonoua) at a rate of 10 samples per city (Grand-Lahou, Dabou and Bonoua).

\section{Analysis of samples}

The metal trace element contents of attiéké samples were quantitatively determined at the Central Laboratory for Food Hygiene and Agro-industry, technical unit of the National Laboratory for Support to Agricultural Development (LANADA) by Atomic Absorption Spectrophotometry (SAA) according to AOAC method 999.10.

\section{Method for determining the content of Metal Trace Elements}

The principle of the method consists first of mineralization with $65 \%$ nitric acid of the sample and then an assay by Atomic Absorption Spectrophotometry (AAS).

\section{Mineralization according to AOAC method 999.10}

In mineralization bombs (teflon), samples ( 0.5 $\pm 0.001 \mathrm{~g}$ ) of the attieke sample were weighed. $5 \mathrm{ml}$ of concentrated $\mathrm{HNO} 3$ and $2 \mathrm{ml}$ of hydrogen peroxide were added in order to destroy all organic matter. In fact, this method consists of transforming the organic sample into a mineral compound.

The Teflon were hermetically sealed and then placed on a hot plate at $120^{\circ}$ C. for $3 \mathrm{~h}$. After digestion, the content of each Teflon was transferred to vials and then made up to $25 \mathrm{ml}$ with distilled water. This solution was injected into the apparatus (SAA) for the determination of the Metal Trace Elements.

To verify that there was no crosscontamination, a blank test was carried out in the absence of matrix (attiéké) with the same quantities of reagents, under the same conditions and subjected to mineralization at the same time as samples.

\section{Determination of arsenic, lead and cadmium by SAA-FG:}

Once the equipment is prepared, the mineralized samples and the blank are placed in wells and then placed at the level of the sample changer of the spectrometer. The standard solution, blank and chemical modifier (ortho-phosphoric acid) was poured into appropriate wells of the AAS.
After plotting the calibration curve, the concentrations of heavy metals in the samples were given by the spectrometer in comparison to the standard range. Assays for arsenic, lead and cadmium were carried out by SAA equipped with a graphite furnace and a sample changer.

\section{Calculation of concentrations}

The mineral concentration is obtained according to the following formula:

$$
\mathrm{C}(\mathrm{mg} / \mathrm{kg})=\frac{((\mathrm{A}-\mathrm{B}) \times \mathbf{f} \times 25)}{\mathrm{m}}
$$

With:

$\checkmark$ A: Crude sample concentration ( $\mathrm{mg} / \mathrm{L}$ )

$\checkmark$ B: White concentration $(\mathrm{mg} / \mathrm{L})$

$\checkmark$ f: Dilution factor

$\checkmark$ 25: The volume of the solution for recovering the digested sample $(\mathrm{ml})$

$\checkmark \mathrm{m}$ : The mass of the sample (g)

\section{Statistical Analysis}

Statistical tests and graphs were made using computer statistical analysis software called grapPhad.Prism.V5.01. The data was analyzed with ANOVA One-Way. Dunnett's nonparametric test was used to compare the variance of the norm to the content of the samples analyzed. The difference between two variances was significant, if $\mathrm{p}<0.05$.

\section{Danger Diagnosis}

The diagnosis of danger is formalized by the report: Measured Concentration/Maximum Regulatory Concentration (CMR) Or Measured Concentration /Recommended Maximum Concentration (CMREC). The danger is considered to be true if the ratio is greater than 1 [12].

\section{RESUlTS}

Table I, below, shows the average levels of Metal Trace Elements in attièké from Grand-Lahou, Dabou and Bonoua. For Grand-Lahou, the average arsenic content was $0.229 \pm 0.050 \mathrm{mg} / \mathrm{kg}$ (Table I), for Dabou, this average content was $0.053 \pm 0.03 \mathrm{mg} / \mathrm{kg}$ (Table I) and $0.039 \pm 0,00 \mathrm{mg} / \mathrm{kg}$ for the city of Bonoua. Regarding lead, for Grand-Lahou, the average content was $0.444 \pm 0.300 \mathrm{mg} / \mathrm{kg}$, for Dabou, this average content was $0.387 \pm 0.281 \mathrm{mg} / \mathrm{kg}$ and $0.451 \pm$ $0.266 \mathrm{mg} / \mathrm{kg}$ for the city of Bonoua. As for cadmium, the average content was $0.0106 \pm 0.0102 \mathrm{mg} / \mathrm{kg}$ for the city of Bonoua (Table I), and for the city of GrandLahou, this average content was below the limit of detection $(0.002 \mathrm{mg} / \mathrm{kg})$ (Table I). For the city of Dabou, the average cadmium content was $0.0110 \pm 0.00$ 
$\mathrm{mg} / \mathrm{kg}$. The average lead content was significantly high and that of cadmium was significantly low compared to the standard (Table I).

Table II shows the diagnosis of the danger. This diagnosis was 1.07 for arsenic, 4.27 for lead and
0.08 for cadmium. Lead has the highest danger diagnosis.

For arsenic and lead, the diagnosis being greater than 1 shows that the danger is real. On the other hand, with regard to cadmium, the danger is not proven (diagnosis $<1$ ).

Table-I: Average levels of Trace Metal Element in the attiéké from the cities of Grand Lahou, Dabou and Bonoua

\begin{tabular}{|l|l|l|l|l|}
\hline \multirow{2}{*}{} & \multicolumn{3}{|c|}{ TOWNS } & standard \\
\cline { 2 - 4 } & Grand-Lahou & DABOU & Bonoua & \\
\hline Arsenic $(\mathrm{mg} / \mathrm{Kg})$ & $0,229 \pm 0,050$ & $0,053 \pm 0,03$ & $0,039 \pm 0,00$ & $0,1 \mathrm{mg} / \mathrm{kg}[13] ;$ \\
\hline lead $(\mathrm{mg} / \mathrm{Kg})$ & $0,444 \pm 0,30^{* *}$ & $0,387 \pm 0,281 *$ & $0,451 \pm 0,266 * *$ & $0,1 \mathrm{mg} / \mathrm{Kg}[8] ; 0,3 \mathrm{mg} / \mathrm{Kg}[2]$ \\
\hline Cadmium $(\mathrm{mg} / \mathrm{Kg})$ & $0,002 \pm 0,00 * * *$ & $0,0110 \pm 0,00 * * *$ & $0,0106 \pm 0,0102 * * *$ & $0,1 \mathrm{mg} / \mathrm{Kg}[8] ; 0,2 \mathrm{mg} / \mathrm{Kg}[2]$ \\
\hline
\end{tabular}

Table-II: Danger diagnosis

\begin{tabular}{|c|c|c|c|l|}
\hline & $\begin{array}{c}\text { Average ETM } \\
(\mathbf{m g} / \mathbf{K g})\end{array}$ & $\begin{array}{c}\text { Danger (Moyenne ETM } \\
\text { /Norme 0,1) }\end{array}$ & standard & Conclusion \\
\hline Arsenic & $0,107 \pm 0,105$ & 1,07 & $0,1 \mathrm{mg} / \mathrm{kg}[13] ;$ & $>1$ (proven danger) \\
\hline lead & $0,427 \pm 0,035$ & 4,27 & $0,1 \mathrm{mg} / \mathrm{Kg}[8] ; 0,3 \mathrm{mg} / \mathrm{Kg}[2]$ & $>1$ (proven danger) \\
\hline Cadmium & $0,008 \pm 0,005$ & 0,08 & $0,1 \mathrm{mg} / \mathrm{Kg}[8] ; 0,2 \mathrm{mg} / \mathrm{Kg}[2]$ & $<1$ (danger not proven) \\
\hline
\end{tabular}

\section{DISCUSSION}

Metal Trace Elements (TME) are the third source of risk for human and animal food after mycotoxins and microorganisms [14]. These Metal Trace Elements have bioaccumulation characteristics. This explains their toxicity. Among the most dangerous are: mercury, lead and cadmium [15]. They are among those who hold the attention of the international community [16].

The study carried out showed the presence of lead, cadmium and arsenic in the cassava semolina (attiéké) samples analyzed from Grand-Lahou, Dabou and Bonoua. However, the average cadmium content remains significantly below the norm $(0.1 \mathrm{mg} / \mathrm{kg})$ while for arsenic; the average content obtained in Grand-Lahou was significantly higher than the norm $(0.1 \mathrm{mg} / \mathrm{kg})$. As for lead, the average content is significantly higher than the norm $(0.1 \mathrm{mg} / \mathrm{kg})$. The work carried out during this study is similar to that of KOUAME [11] and KOUAME et al., [18], where the lead content was $6.24 \pm 0.58 \mathrm{mg} / \mathrm{kg}$ in the cooked attiéké on the abobo market, $6.25 \pm 0.06 \mathrm{mg} / \mathrm{kg}$ on the Adjamé market, $3.8 \pm 0.4 \mathrm{mg} / \mathrm{kg}$ in Dabou and $2.2 \pm$ $0.1 \mathrm{mg} / \mathrm{kg}$ in Grand-Lahou. As for cadmium, according to KOUAME [17], the cadmium content was $0.07 \pm 0.05 \mathrm{mg} / \mathrm{kg}$ and $0.06 \pm 0.03 \mathrm{mg} / \mathrm{kg}$ respectively on the market of Abobo and Adjamé. In Dabou, the cadmium content was $0.03 \pm 0.01 \mathrm{mg} / \mathrm{kg}$ and $0.06 \pm 0.02 \mathrm{mg} / \mathrm{kg}$ in Grand-Lahou [18].

The presence of trace metal elements in food products requires the search for the source of contamination according to Fangnon et al. [15]. The presence of TME in the samples analyzed in this study could be explained by the fact that the Metal Trace Elements are dissolved in rainwater or irrigation water.
Thus, plants capture Metal Trace Elements in the soil without any known metabolic function (for example $\mathrm{Cd}$, $\mathrm{Hg}, \mathrm{Pb}, \mathrm{As}$, etc.) and therefore considered as "nonessential" [12]. Poultry manure and sawdust used as fertilizer for agricultural land are a source of contamination of trace metal elements [19]. Indeed, during their work, Capo-Chichi et al. [8] determined a high content of cadmium and lead in cassava roots. As for Kalonda et al. [2], they for their part observed a strong presence of lead and cadmium in cassava leaves.

In Abidjan, Dabou and Grand-Lahou, the cassava variety IAC (Improved African Cassava) is the most used for the production of cassava semolina (attiéké) [18]. However, the packaging of this attieké during production is done in transparent plastic bags (PE) after a slight cooling. According to a study conducted by Musoke et al. [20], the metallic trace elements constituting the plastic bag are sources of food contamination and their migration increases with the variation of temperature and time. Therefore, the use of plastic bags for packaging attiéké exposes consumers to metal poisoning. In addition, it has been observed that the wind is used as a parameter for air drying of attieké, which could be a source of contamination according to KOUAME [21]. Some cassava fields are located by the roadside, exposing cassava plants to dust, automobile and motorcycle exhaust which are very rich in trace metal elements [22].

According to a survey conducted by KOUAME [21], women producers obtained water from wells, the lagoon and rivers for the production of attiéké. Same observation made by Adingra and Kouassi, [23] where women use water from the lagoon for cooking attiéké and cleaning utensils throughout the production process. They thus expose consumers to the 
risks of diseases linked to the contamination of attiéké by certain Trace Metal Elements present in the lagoon. This practice is due to the fact that almost all of the attiéké produced is made in a traditional way [24] and sold on informal markets [4]. Thus, the contamination of the attiéké by metallic trace elements could be linked to the raw material, to certain elements involved in the transformation process as well as to the poor maintenance of the processing equipment. The ingestion of these contaminated foods could therefore cause dysfunction in humans [25].

The study carried out showed that the diagnosis of the danger being greater than 1 for arsenic and lead proves that the danger associated with the consumption of attiéké from the cities of Grand-Lahou, Dabou and Bonoua is true. Thus, after ingestion, these metallic trace elements are transported in the blood and stored at the level of the target organ, which varies depending on the metal, arsenic: heart; lead: bone [26]. Arsenic causes lung cancer and is toxic to the heart. As for lead, it causes encephalopathies, kidney damage, and anemia and modifies the biology of the cell by disrupting many metabolic ions [26].

In Abidjan, more than $47 \%$ of households consume attiéké at least once a day with fish or meat [24] due to $28 \mathrm{~kg}$ and $30 \mathrm{~kg}$ per capita / year [1]. For better consumer protection, Capo-Chichi et al. [8] recommend that preventive sanitary measures be applied so that cassava tubers and the water used are of good quality and that processing equipment is well maintained, according to the standards of Good Hygiene Practices (BPH) in force throughout the production chain.

\section{CONCLUSION}

The study carried out showed the presence of metallic trace elements in cassava meal (attiéké) from three towns in Côte d'Ivoire. The activity of producing attiéké is artisanal and the sale takes place in informal markets where the volume of production extends beyond the Ivorian border. The market for the sale of attiéké is a market that deserves to be cleaned up given its socio-economic importance. The establishment of a guide to good hygiene practice in this sector would be the first step towards a formal transformation of this job-creating activity. It is also the place to organize, educate and train stakeholders in the sector to protect the health of consumers.

\section{REFERENCES}

1. Regina, K. E., Antoine, A. A., Fafadzi, E. A., Diawara, B., Sébastien, N. L., \& Philippe, T. (2015). Production d'attieke (couscous à base de manioc fermente) dans la ville d'Abidjan. European scientific journal, 11(15).

2. Kalonda, D. M., Tshikongo, A. K., Koto, F. K. K., Busambwa, C. K., Bwalya, Y. K., Cansa, H. M., ...
\& Otshudi, A. L. (2015). Profil des métaux lourds contenus dans les plantes vivrières consommées couramment dans quelques zones minières de la province du Katanga. Journal of Applied Biosciences, 96, 9049-9054.

3. Faostat. (2013). Bases de données statistiques du Fonds des Nations Unies pour l'Alimentation et l'Agriculture. www.faostat.org

4. Yéboué, K. H., Amoikon, K. E., Kouamé, K. G., \& Kati-Coulibaly, S. (2017). Valeur nutritive et propriétés organoleptiques de l'attiéké, de l'attoukpou et du placali, trois mets à base de manioc, couramment consommés en Côte d'Ivoire. Journal of Applied Biosciences, 113(1), 11184-11191.

5. CNRA Info. (2003). Bulletin D'information Et De Liaison Du Cnra. $N^{\circ} 008: 1-8$

6. Kakou, A. C. (2000). Optimisation des conditions d'application d'une méthode de conservation longue durée de la pâte de manioc (Manihot esculenta, Crantz) en vue d'améliorer la qualité alimentaire de l'attiéké et du placali. PhD Report, University of Cocody (Côte d'Tvoire) $\mathrm{Pp}, 123$.

7. Guira, F. (2013). Evaluation des valeurs nutritive et sanitaire d'attiéké issu de différentes pâtes de manioc importées ou produites localement à partir de différents ferments. Diplôme d'Etudes Approfondies en Biotechnologies, Burkina Faso, 79.

8. Capo-Chichi, R., Tchibozo, M. A. D., Adoukonousagbadja, H., Anago, D. G., Ayi-Fanou, L., Karou, S. D., ... \& De Couza, C. (2013). Évolution du ph et des microflores fermentaires de agbelima produit à Pahou au Bénin. Journal de la Recherche Scientifique de l'Université de Lomé, 15(2), 1-11.

9. Park, J., Kim, J. Y., \& Kim, K. W. (2012). Phytoremediation of soil contaminated with heavy metals using Brassica napus. Geosystem Engineering, 15(1), 10-18.

10. Adjagodo, A. (2018). Influence des activités anthropiques sur la qualité des ressources en eau de surface dans la Basse Vallée du fleuve Ouémé. Thèse de doctorat, Université d'Abomey-Calavi, Abomey-calavi, 289.

11. Kouamé, K.A. (2013). Identification des dangers et des points critiques de contrôle pour la mise en place d'un système HACCP pour la production de l'attiéké en Côte d'Ivoire. Thèse de doctorat l'Université Nangui Abrogoua en Côte d'Ivoire, 191.

12. Mench, M., \& Baize, D. (2004). Contamination des sols et de nos aliments d'origine végétale par les éléments en traces.

13. Ouro-Sama, K., Solitoke, H., Gnandi, K., Afiademanyo, K., \& Bowessidjaou, E. (2014). Évaluation et risques sanitaires de la bioaccumulation de métaux lourds chez des espèces halieutiques $\mathrm{du}$ système lagunaire 
togolais. [VertigO] La revue électronique en sciences de l'environnement, 14(2).

14. Dauguet, S., Denaix, L., Nguyen, C., Royer, E., Levasseur, P., Potin-Gautier, M., Lespes, G., Parat, C., Héroult, J., Coudure, R., Chéry, P., Devert, M., Robert, N., Pouech, P. (2011). Mesure des flux d'éléments traces $(\mathrm{Pb}, \mathrm{Cd}, \mathrm{As}, \mathrm{Cu}, \mathrm{Zn})$ dans les sols, végétaux, porcs et lisiers des exploitations porcines du Sud-Ouest. Innovations Agronomiques, $17: 175-190$.

15. Bernard, F., Patient, T. A. Y. G., \& Patrick, E. A. (2012). Conservation des produits agricoles et accumulation des métaux lourds dans les produits vivriers dans le département du Couffo (Benin). Journal of Applied Biosciences, 57, 41684176.

16. Guédénon, P. (2009). Pollution des écosystèmes par les métaux lourds $(\mathrm{Cd}, \mathrm{Pb}, \mathrm{Cu})$ : Cas du fleuve Ouémé et du lac Nokoué. Mémoire de DESS Sciences de l'environnement et développement durable, CIFRED, UAC, 95p.

17. Djeni, N. T., Kouamé, K. A., Bouatenin, M. K. J. P., N'Guessan, K. F., \& Dje, K. M. (2014). Processus de production de l'attiéké" en Côte d'Ivoire: les nouvelles tendances, les mises à jour et les effets sur la qualité et la préférence du mets. International Journal of Advanced Research, 2(8), 644-653.

18. Alfred, K. K., Jean Paul, B. K. M., Théodore, D. N. D., \& Marcellin, D. K. (2019). Microbiological and chemical hazards of commercial attieke (a fermented cassava product) produced in the south of Côte d'Ivoire. Food Quality and Safety, 3(3), 187-190.
19. Diaby, V., Adon, A. M., Dosso, M., \& Yapo, A. F. (2017). Problématiques du cadmium en Côte d'Ivoire: Pollution environnementale et risque sanitaire.

20. Musoke, L., Banadda, N., Sempala, C., \& Kigozi, J. (2015). The migration of chemical contaminants from polyethylene bags into food during cooking. The Open Food Science Journal, 9(1).

21. Kouame Kouakou Delphin. (2016). Etude prospective des conditions d'hygiène du processus de production de l'attieke à Anyama, abobo-baoulé et yopougon-kouté, Université Nangui Abrogoua. UFR des sciences et technologies des aliments. Mémoire; Biochimie et Technologies des Aliments, 53 pages

22. Kunwar, S., \& Mathai, G. (2004). U.S. Patent Application No. 10/335,482.

23. Adingra, A. A., \& Kouassi, A. M. (2011). Pollution en lagune Ebrié et ses impacts sur l'environnement et les populations riveraines.

24. Aubin, D. D. P. (2016). Taille des grains de l'attieke de trois zones traditionnelles de production grand labou, abidjan et dabou (Doctoral dissertation, Université Nangui Abrogoua).

25. Li, Q., Chen, Y., Fu, H., Cui, Z., Shi, L., Wang, L., \& Liu, Z. (2012). Health risk of heavy metals in food crops grown on reclaimed tidal flat soil in the Pearl River Estuary, China. Journal of hazardous materials, 227, 148-154.

26. Dehon, B., Nisse, C., Lhermitte, M., \& Haguenoer, J. M. (2001). Métaux et médecine du travail. In Annales de Toxicologie Analytique (Vol. 13, No. 3, pp. 203-219). EDP Sciences. 